\title{
Characterization of foraminifera in the southern East Sea during the late Holocene
}

\author{
Chi Kim Thi Ngo ${ }^{1}{ }^{*}$, Bat Van Dang 2 \\ ${ }^{1}$ Hanoi University of Mining and Geology, Hanoi, Vietnam \\ 2 Vietnam Union of Geological Sciences, Hanoi, Vietnam
}

ARTICLE INFO ABSTRACT

Article history:

Received 08 ${ }^{\text {th }}$ Aug. 2021

Revised 01 ${ }^{\text {st }}$ Nov. 2021

Accepted 28 ${ }^{\text {th }}$ Nov. 2021

Keywords:

Foraminifera,

Late Holocene,

Southern East Sea.
Twenty marine sediment samples have been collected in the Quaternary sediments in the southwest deep-depression East Sea region to study the foraminifera's characterization. By analyzing foraminifer components under a microscope and taking photos under SEM, the authors determined that foraminifera fossils in the research area belonged to 01 sub-ordo as per the classification system proposed by Loeblich A.R. and Tappan H., which is Globigerinina Delage and Hérouard, 1896 sub-ordo, including four families, ten genera and 24 species. 04 families are Globigerinidae (06 genera and 13 species), Globorotaliidae (with two genera and nine species), Pulleniatidae (one genus and one species), and Catapsydracidae (one genus and one species). They all belong to the planktonic foraminifer group, living in the deep sea. Their indicator ages range from Miocene to Recent.

\section{Introduction}

Foraminifer is the subject of research in geology to solve environmental problems forming sediments, stratigraphy, and paleo-geography (Loeblich, 1988; Billups et al., 2002; Hanebuth et al., 2011; Ngo Thi Kim Chi et al., 2015, 2016, 2020; Nguyen Huu Cu, Mai Van Lac, 1996; Nguyen Ngoc, 2018; Pham Nhu Sang et al., 2020). However, there are just few research papers on this fossil

${ }^{*}$ Corresponding author

E - mail: ngothikimchi@humg.edu.vn DOI: 10.46326/JMES.2021.62(6).02 group in marine sediments in Vietnam in general and in the marine area in particular. The available scientific work on foraminifer in Vietnam is "Foraminifer Kainozoic in the continental shelf and surrounding areas in Vietnam" by Nguyen Ngoc et al. (2006). The authors identified and detailed 241 species belonging to 90 genera, 49 families, and six sub-ordos of foraminifer. There are also several works by Nguyen Huu Cu (1996), Ngo Thi Kim Chi $(2015,2016,2020)$, Nguyen Ngoc (2018), also concerned with foraminifer in Vietnam. However, most of these works were the samples collected in the continental, coastal, and shallow sea, thus, foraminifer species specific to deep sea have not been studied so far. 
The research area in this work is the southwest deep-depression East Sea region, defined by coordinates $109^{0} 15^{\prime} 46^{\prime \prime} \div 111^{0} 45^{\prime} 51^{\prime \prime}$ East longitude and from $8^{0} 59^{\prime} 37^{\prime \prime} \div 11^{\circ} 00^{\prime} 58^{\prime \prime}$ North latitude (Figure 1). The study area's topography is controlled by three major tectonic zones of the earth's crust. They are continental shelf, continental slope, and seafloor. The continental shelf is located in the west of the study area, and the topographic surface has a depth of $0 \div 200 \mathrm{~m}$. The continental slope in the southwestern region of the East Sea is a steep, relatively large slope formed with tectonic origin closely related to the fault zone of the East side of the Vietnam continental shelf. The seafloor is distributed under continents extending from depths of $1300 \mathrm{~m}$ to more than $3000 \mathrm{~m}$. The surface of the seafloor is relatively flat, with some guyots and seamounts (Figure 1).

\section{Materials and methods}

\subsection{Materials}

This paper is written based on the obtained results of the analysis of 20 surface sediment samples collected during the southwest deepdepression East Sea region investigation, a part of the National Project No KC.09.30/16-20 "Research on stratigraphy and geomorphology Pliocene-Quaternary in the southwest deepdepression East Sea region and surrounding", and results of the project T20-29, supported by the Hanoi University of Mining and Geology.

\subsection{Methods}

In this paper, the authors apply the method of microfossil analysis - analyzing the composition of Foraminifera under a microscope.

Sediment samples collected from the field were processed using specialized tools. The processing samples includes the following steps:

- Washing the samples with clean water to obtain a composition of hard, crumbs and fossils.

- The residual samples are dried in an oven at $60^{\circ} \mathrm{C}$ for 1 day. When the samples dry, the processing is completed.

- The processed samples are stored in plastic bags or boxes with the sample numbers for analysis.

- Analysis of the composition of Foraminifera under the microscope: The purpose of analyzing samples is to determine the scientific name of foraminifers in the samples and assess their ecological characteristics. The authors used the

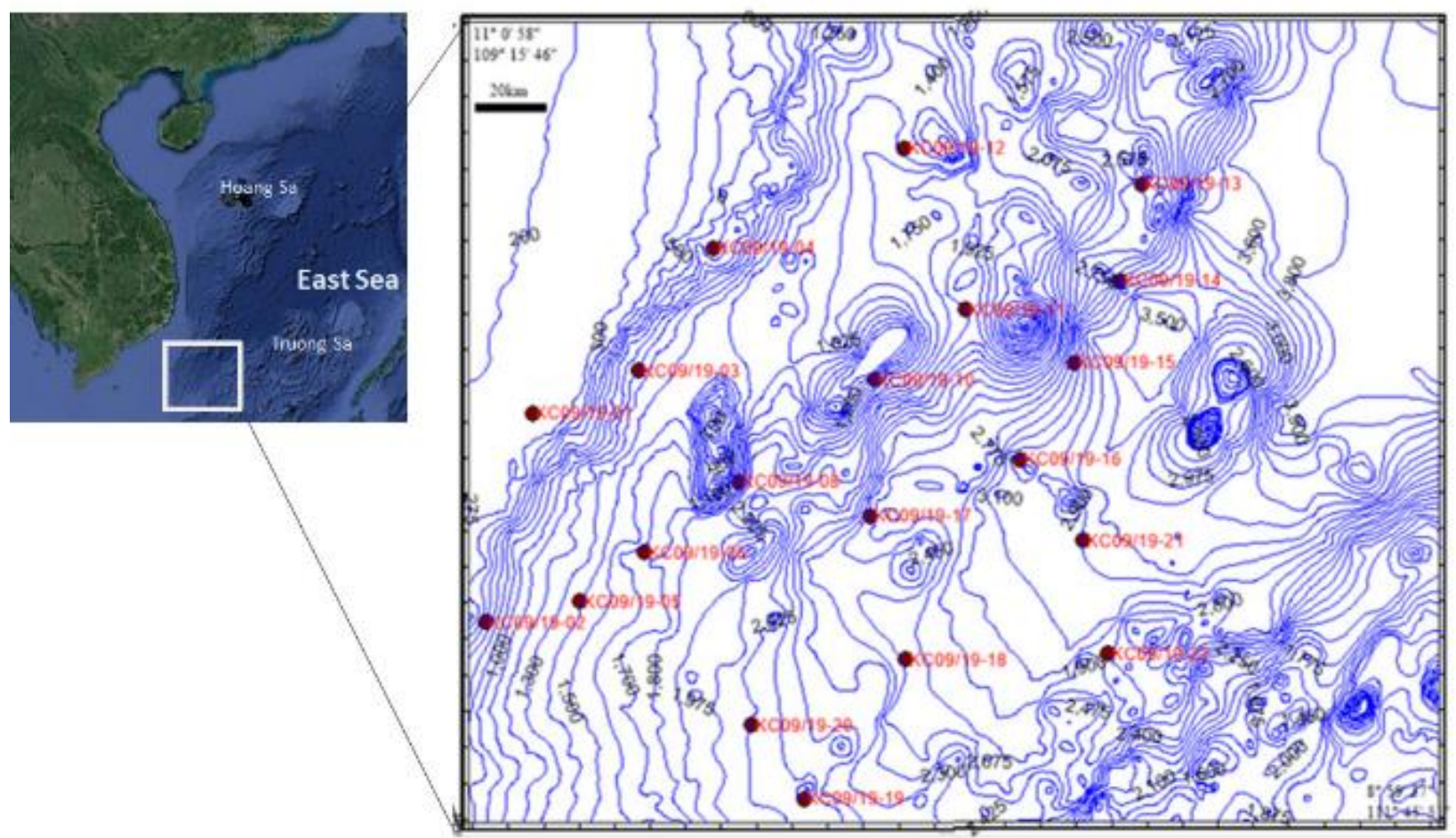

Figure 1. Location and bathymetry of the research area and the sampling stations in the southern East Sea. 
microscope to observe and study the outside, the internal morphological structures, and the characteristic features of the fossils, then compare the references to obtain all information related to the breed and species and define their scientific names. The sample determination results are to establish a list of foraminifera fossils as per the classification system proposed by Loeblich and Tappan $(1964,1988)$.

- Take fossil photos by Scanning Electron Microscope (SEM): For samples after being analyzed (identified), the authors select and take samples' pictures by SEM at the Center for HighTech Analysis of the Hanoi University of Mining and Geology. The obtained photos are illustrated in this paper.

\section{Results and discussion}

\subsection{The characteristics of genus and species composition}

Based on the obtained results of analyzing 20 marine sediment samples, the authors have determined that foraminiferal fossils in the research area belong to 01 sub-ordo as per the classification system proposed by Loeblich and Tappan (1988), where Globigerinina is the most dominant in the genus, species, including 06 genus and 13 species, follows by Globorotaliidae (with two genera and nine species), Pulleniatidae (one genus and one species) and Catapsydracidae (one genus and one species). Details of the genus, species composition of foraminifers in the researched area are as follows.

\section{a. Globigerinidae family}

Globigerinidae family includes 06 genus and 13 species (Table 1), namely:

- Globigerinoides genus includes six species (Globigerinoides trilobus, G. sacculifer, G. ruber, G. bulloides, $G$. rubescense, $G$. falconensis). The test is of an oval shape, arranged in a spiral buried vortex with increasing rings. The last ring has $3 \div 4$ chambers, separated by deep stitching grooves. The aperture is of a low arched, widening in the umbilical cord. The wall is not solid but filled with holes. The diameter of the case is $0.38 \div 0.65 \mathrm{~mm}$ (Figure 2). This variety is widely grown in the Pacific and Indian Oceans, clearly indicating age from Pliocene to Recent (Loeblich and Tappan, 1988).

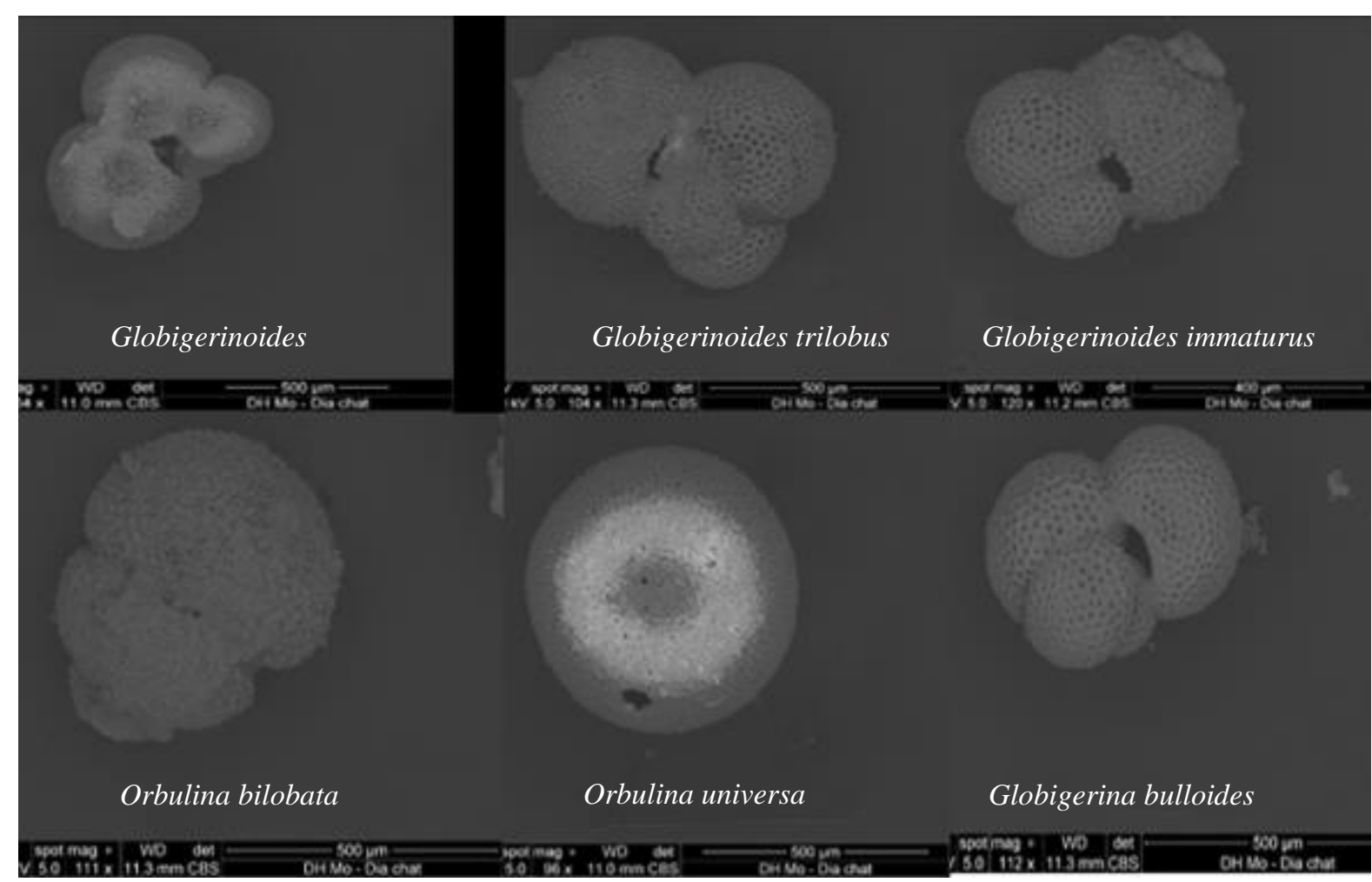

Figure 2. Some species of the Globorotaliidae family in the research area. 
Table 1. The foraminiferal genus, species composition belong to Globigerinidae family in the research area.

\begin{tabular}{|c|c|l|}
\hline N0 & Genus & \multicolumn{1}{c|}{ Species } \\
\hline 1 & Globigerinoides & $\begin{array}{l}\text { - Globigerinoides } \\
\text { trilobus } \\
\text { - G. sacculifer } \\
\text { - G. ruber } \\
- \text { G. bulloides } \\
\text { - G. rubescense } \\
\text { - G. falconensis }\end{array}$ \\
\hline 2 & Orbulina & $\begin{array}{l}\text { - Orbulina universa } \\
\text { - Orbulina bilobata }\end{array}$ \\
\hline 3 & Sphaeroidina & $\begin{array}{l}\text { - Sphaeroidina } \\
\text { bulloide } \\
\text { - Sphaeroidina sp. }\end{array}$ \\
\hline 4 & Globigerinella & $\begin{array}{l}- \text { Globigerinella } \\
\text { siphonifera }\end{array}$ \\
\hline 5 & Globigerina & - Globigerina calida \\
\hline 6 & Sphaeroidinellopsis & $\begin{array}{l}\text { - Sphaeroidinella } \\
\text { dehiscens }\end{array}$ \\
\hline
\end{tabular}

- Orbulina genus has two species (Orbulina universa and Orbulina bilobata). The test spherical, final chamber completely encloses the early five chambers stage. The wall is perforated. No primary aperture is seen. The length and width of the case are $0.41 \div 0.63 \mathrm{~mm}$ and $0.3 \div 0.45 \mathrm{~mm}$ accordingly (Figure 2). The Orbulina variety is very popular in many marine areas in the world, age ranging from the Miocene to recent (Loeblich and Tappan, 1988; Nguyen Ngoc et al., 2006).

- Sphaeroidina genus includes two species (Sphaeroidina bulloide, Sphaeroidina sp.). The test is of an oval shape, consisting of three chambers with large swelling. Stitching grooves are small, shallow, and often unclear. The aperture in the equatorial groove is covered by the outer edge of the last chamber. The wall consists of large holes, small spikes often cover the surface. The test length and width are $0.52 \div 0.59 \mathrm{~mm}$ and $0.41 \div 0.52 \mathrm{~mm}$ accordingly. These varieties widely exist in the Pacific, Indian, and Mediterranean oceans and indicate age from Pliocene to recent (Loeblich and Tappan, 1988; Nguyen Ngoc et al., 2006).

- Globigerinella genus has only one species, Globigerinella siphonifera, the test has a shape of coiled chambers in an enclosed plane. The last ring has 5 or 6 chambers with diameters from $0.35 \div 0.5 \mathrm{~mm}$. In the world ocean, it is found in many areas indicating age from Miocene to Holocene (Loeblich and Tappan, 1988; Nguyen Ngoc et al., 2006). It was found in Quaternary in Vietnam (Loeblich and Tappan, 1988; Nguyen Ngoc et al., 2006).

- Globigerina genus has Globigerina calida species. The test has a low spiral conical structure. The last ring has four chambers, which tends to develop long and long with large diameter. Aperture is wide, low, small lip lines. Diameter is $0.3 \div 0.5 \mathrm{~mm}$. The wall is thin and fragile. Globigerina calida is widely found in marine sediments in the Pacific ocean, indicating the age from Holocene to recent (Loeblich and Tappan, 1988; Nguyen Ngoc et al., 2006).

- Sphaeroidinellopsis genus has Sphaeroidinella dehiscens species. The test is characterized by triangular or sub-quadangular shape, low spiral conical structure. The aperture opens at the navel, demonstrating a surrounding thin lip. The shell wall is composed of large holes. Its diameter is 0.4 $\mathrm{mm}$. In the world, this species is found in many areas of Indian, Pacific. In Vietnam, it is also found in sediments in the lowlands of Hanoi, indicating age from Miocene to Holocene (Loeblich and Tappan, 1988).

\section{b. Globorotaliidae family}

Globorotaliidae family includes 02 genus and 09 species (Table 2), as follows:

Table 2. The foraminiferal genus, species composition belong to Globorotaliidae family in the research area.

\begin{tabular}{|c|c|c|}
\hline $\mathrm{N}^{0}$ & Genus & Species \\
\hline 1 & Globorotalia & $\begin{array}{l}\text { - Globorotalia menardii } \\
\text { - Globorotalia tumida } \\
\text { - G. flexuosa } \\
\text { - G. bermudezi } \\
\text { - G. cultrata } \\
\text { - G. truncatulinoides } \\
\text { - G. ungulata } \\
\text { - G. scitula } \\
\end{array}$ \\
\hline 2 & Neogloboquadrina & $\begin{array}{l}\text { Neogloboquadrina } \\
\text { acostaensis }\end{array}$ \\
\hline
\end{tabular}

- Globorotalia genus has a rich number of species (eight species of Globorotalia menardii, G. 
tumida, G. flexuosa, G. bermudezi, G. cultrata, G. truncatulinoides, G. ungulata, G. scitula). The test is flat, round oval shape, lightly bulging, the last ring has seven chambers, the last three chambers are large (Figure 3). At the shell's outer edge forming a narrow angle, around the edge, the wall is made of small holes. Its diameter is up to 0.7 $\mathrm{mm}$. Globorotalia genus is widely distributed in many seas. Especially in Vietnam, the fossils of this group were recorded in Miocene up to recent sediments.

- The Neogloboquadrina genus has only one species, Neogloboquadrina acostaensis (Figure 3). The test has a low conical spiral structure, and the final growth ring has six spherical chambers separated by deep grooves on the dorsal and ventral surfaces. The outer edge of the shell is round. The wall is made of big holes. The diameter is $0.6 \mathrm{~mm}$. It is widely distributed in the Pacific Ocean, appearing from Miocene, common in Pliocene, to Holocene.

\section{c. Pulleniatidae family}

Pulleniatidae family includes one genus Pulleniatina and 01 species of Pulleniatina obliquiloculata. The test has a final growth ring that embraces the back and abdomen. The aperture is wide, arched, and the lips are underdeveloped. Stitching grooves are small and shallow. The wall is smooth and has no pattern. This genus is distributed in from Japan to New Zealand seas. Age indicates from Pliocene to Quaternary (Loeblich and Tappan, 1988; Nguyen Ngoc et al., 2006).

\section{d. Catapsydracidae family}

Catapsydracidae family includes one genus Globoquadrina and one species which is Globoquadrina conglobatus. The test is of a low twisted pyramid structure, and the back is less bulging than the abdomen. The final growth ring has four spherical, flattened chambers. The navel test is trapezoidal, narrow, and deep. The wall is made of holes. The diameter is from $0.22 \div 0.45$ $\mathrm{mm}$. Globoquadrina conglobatus is common in the Pacific and Indian oceans. The indicating age is from Pliocene to Quaternary (Loeblich and Tappan, 1988; Nguyen Ngoc et al., 2006).

\subsection{Paleoecological characteristics}

Foraminifer species in the researched area are mostly spherical, bulging like balls, small, and light. They all have planktonic features, suitable for living in a quiet water environment (no large flow), in the deep sea, stable temperature, and salinity.

The prevalence of fossils is highly present in the samples, containing many numbers and species composition, but they belong to only one Globigerinina sub-ordo. It is a remarkable difference compared to previous studies (Ngo Thi Kim Chi et al., 2015, 2016, 2020; Nguyen Huu Cu, Mai Van Lac, 1996; Nguyen Ngoc, 2018) in coastal and shallow sea areas.

\section{Conclusions}

Surface sediments in the southern East Sea were employed to investigate the characterization of foraminifers during the late Holocene. Through this study, we conclude that:

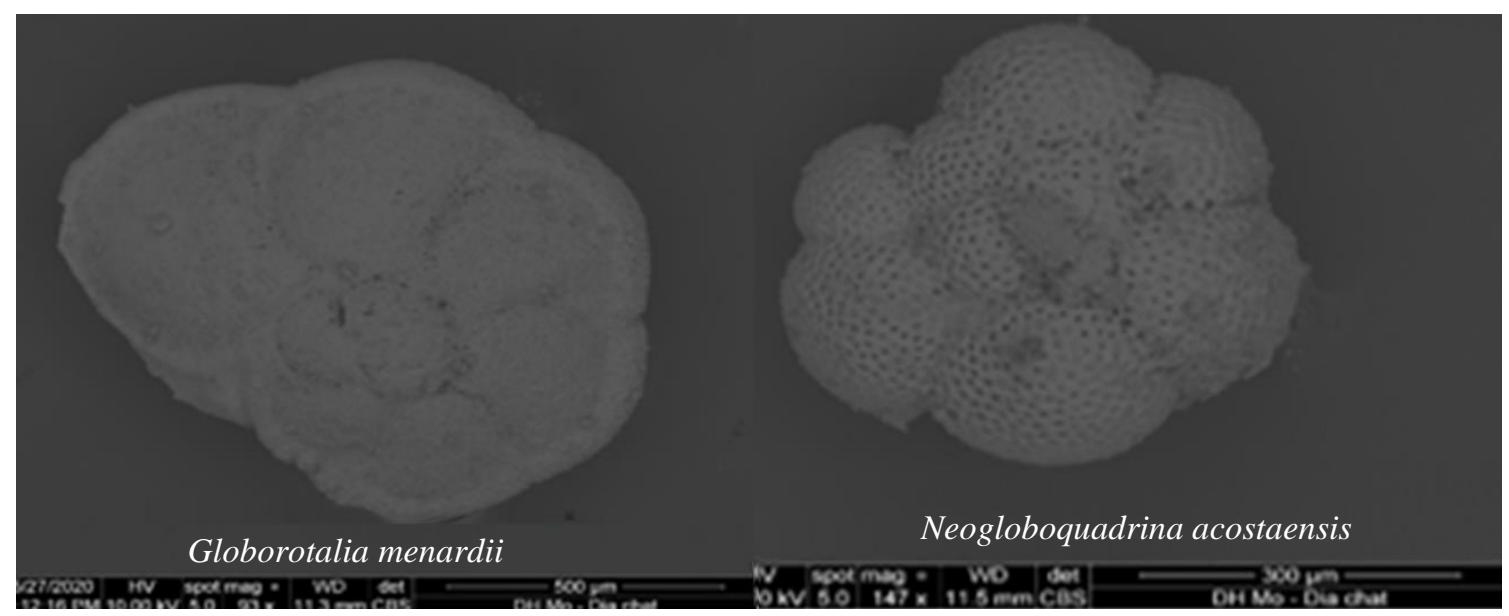

Figure 3. Some species of the Globorotaliidae family in the research area. 
Surface sediments in the research area are plentiful foraminifers but belong to only one subordo of fossils. The foraminifers consist of Four families, ten genera, and 24 species. Four families include Globigerinidae (six genera and 13 species), Globorotaliidae (with two genus and nine species), Pulleniatidae (one genus and one species), and Catapsydracidae (one genus and one species).

All of the foraminifers are plankton, and they live in the deep sea, implying that surface sediments in the region are formed in the deepsea environment. These foraminifers in marine sediments can find in Miocene, Pliocene, and Holocene in the East Sea, implying that the marine environment has not been significantly changed since Miocene.

\section{Acknowledgments}

This research is funded by National Project No KC.09.30/16-20 and partly supported by the Hanoi University of Mining and Geology under grant number T20-29.

\section{Author contributions}

Chi Kim Thi Ngo prepared manuscript. Bat Van Dang give a critical review for the final version to be submitted.

\section{References}

Billups K., Channell J. E. T., and Zachos J. C. (2002). Late Oligocene to early Miocene geochronology and paleoceanography from the subantarctic South Atlantic. Paleoceanography, 17,4-1-4-11.

Hanebuth T. J. J., Voris H. K., Yokoyama Y., Saito Y., Okuno J. (2011). Formation and fate of sedimentary depocentres on Southeast Asia's Sunda Shelf over the past sea-levelcycle and biogeographic implications. Earth-Science Reviews, 104, 92-110.

Loeblich A. R. Jr., Tappan H. (1964). Treatise in invertebrate paleontology. Ptc. Portista New-York Geol.Soc.Amer.Univ.Kansas. Press
Loeblich A. R. Jr., Tappan H. (1988). Foraminiferal genera and their classification. Department of Earth and Space sciences and Center for the study of Evolution and the origin of Life University of California, Los Angeles, 21-114.

Ngo Thi Kim Chi, Hoang Van Long, Nguyen Minh Quyen, Phan Văn Binh, Bui Vinh Hau, Pham Thi Thanh Hien, Hoang Thi Thoa,( 2020). Foraminifera fauna in the Holocene marine sediments at the shallow sea from Phu Loc (Thua Thien- Hue) to Hoi An (Quang Nam) (0$60 \mathrm{~m}$ of water depth), Earth Sciences and Natural Resources for Sustainable Development Processding. 27-32

Ngo, T. K. C., Mai, V. L., and Dao, V. N. (2016). Foraminifers in the marine sedimentation of the coastal zone in Thua Thien Hue area. Journal of Geology, 355, 83-90.

Ngo, T. K. C., Mai, V. L., and Dao, V. N. (2015). Foraminifera complexes in the sediment of surface layer in Thua Thien-Hue - Da Nang coastal zone (0 - 30M of water depth). Journal of Mining and Earth Science, 51, 13-20

Nguyen, H. C., and Mai, V. L. (1996). Foraminifers in the sedimentation in Tam Giang-Cau Hai lagoon. Marine environmental resources, vol III. Scientific and Technical Publishing Company, Hanoi, 177-185.

Nguyen, N. (2018). Holocene Foraminifera fauna at the region of Phan Vinh island, Truong Sa archipelago and some related problems. Vietnam Journal of Marine Science and Technology, 1, 39-51.

Nguyen, N., Nguyen, H. C., Do, B. (2006). Foraminifer Kainozoic in the continental shelf and surrounding areas in Vietnam. Vietnam Academy of Science and Technology, Hanoi, 392 pages.

Pham, N. S., Dang, V. B., Nguyen, H. H., Ngo, T. K. C, \& Phan, V. B., (2020). Characteristics of sediment provenance in the southwestern East Sea. Journal of Mining and Earth Sciences, 61(5), 11 -19. 